\title{
Documentário e memória: os usos do testemunho em Nostalgia de la luz
}

\begin{abstract}
Samuel Torres Bueno ${ }^{1}$
Resumo: Neste artigo visamos esboçar uma chave de leitura do documentário Nostalgia de la Luz, do chileno Patricio Guzmán, a partir da identificação dos possíveis usos da memória observáveis ali. Esse filme, um dos mais notórios da filmografia de Guzmán, busca interligar as atividades de três grupos que possuem o deserto do Atacama como cenário da investigação do passado: os astrônomos, os arqueólogos e as mulheres que, vasculhando aquela imensidão árida almejam encontrar os restos dos seus familiares desaparecidos pela ditadura militar no Chile. Além disso, há a presença de sobreviventes dos campos de tortura e extermínio daquele regime autoritário. Dessa maneira, os nossos propósitos são: destrinchar como o documentário trabalha com os depoimentos dos seus personagens; o que poderia significar esse trabalho da memória; quais são os sentidos plausíveis dos testemunhos da obra, e quais são as práticas memorialísticas realizadas pelo documentário.
\end{abstract}

Palavras-chave: Memória; Testemunho; Patrício Guzmán; Ditadura Chilena.

\section{Documentary and Memory: The Uses of Testimony in Nostalgia For The Light}

\begin{abstract}
In this article, we aim at outlining a key to understand the documentary Nostalgia de la Luz, by Chilean Patricio Guzmán, based on the identification of the possible uses of memory observed there. This film, one of the most notorious in Guzmán's filmography, seeks to interconnect the activities of three groups that have the Atacama desert as the setting for investigating the past: astronomers, archaeologists and women who, searching that arid immensity, aim to find the remains of his family members who disappeared during the military dictatorship in Chile. In addition, there are survivors from the torture and extermination camps of that authoritarian regime. In this way, our purposes are: to clarify how the documentary works with the testimonies of its characters; what could this work of memory mean; what are the plausible meanings of the work's testimonies and what are the memorialistic practices performed by the documentary.
\end{abstract}

Keywords: Memory; Testimony; Patricio Guzmán; Chilean Dictatorship.

Artigo recebido em: 27/06/2020

Artigo aprovado para publicação em: 07/09/2020

\footnotetext{
${ }^{1}$ Mestre em História em Universidade Federal de Ouro Preto (UFOP). Endereço para correspondência: Rua Amable Perez Rodrigues, n 154, Bairro Padre Pinto, Rio Piracicaba. E-mail: samueltorresbueno@gmail.com. 


\section{Introdução}

"Un país sin cine documental es como una familia sin un álbum de fotografías". Essa afirmação, do cineasta chileno Patricio Guzmán (1941-), indica uma preocupação recorrente na sua filmografia. Assim, para Guzmán, se no âmbito privado os registros fotográficos mantêm vivas as recordações familiares, no plano coletivo os documentários cumprem uma função análoga. Os álbuns e os filmes documentais expressariam, segundo essa ótica, uma obrigação ética de se conservar e transmitir lembranças.

Deste modo, questões delicadas que giram em torno das memórias relacionadas ao passado recente chileno constituem um tema constantemente revisitado pelo diretor, que é considerado um dos mais importantes cineastas latino-americanos. A sua carreira é caracterizada por produções amplamente premiadas em importantes festivais de cinema mundo afora, como os de Cannes e o de Berlim. Ele também é um dos criadores do FIDOCS (Festival Internacional de Documentales de Santiago), além de ministrar diversos cursos sobre cinema documental. Pode-se dizer então que a filmografia de Patricio Guzmán se dedica primordialmente a eventos que marcaram a história chilena nas últimas décadas: o breve, mas intenso período da Unidade Popular ${ }^{2}$, o violento golpe de Estado de 11 de setembro de 1973 e a posterior ditadura militar liderada por Augusto Pinochet (1973-1990).

Nesse sentido, uma das obras mais importantes e premiadas ${ }^{3}$ dentro da trajetória de Guzmán trata-se de Nostalgia de la Luz (2010), objeto da nossa atenção nesse trabalho. Nessa

\footnotetext{
${ }^{2}$ Em linhas muito gerais, pode-se afirmar que a Unidade Popular foi a coligação de muitos partidos e grupos de esquerda que elegeu Salvador Allende em 1970, sob a bandeira da "via chilena ao socialismo". Tratou-se de uma transição para o socialismo por meio de reformas estruturais no sistema econômico com respeito à legalidade e às instituições democráticas. Se em Cuba o caminho para a revolução foi traçado pela via da guerrilha e da ruptura violenta, no Chile essa transformação radical seria implantada dentro dos limites reformistas e das vias institucionais. A experiência da Unidade Popular foi ferozmente interrompida pelo golpe de Estado de 1973. Dentro do contexto da Guerra Fria, as Forças Armadas chilenas, com o apoio maciço dos EUA, cercaram e bombardearam La Moneda, o palácio presidencial, e em seguida impuseram a ditadura.

${ }^{3}$ Dentre as honrarias que Nostalgia de la Luz recebeu em festivais, podemos destacar os seguintes: melhor documentário europeu pela Academia Europeia de Cinema (2010); Seleção Oficial de Cannes (2010), Menção Especial do Júri do Prêmio François Chalais em Cannes (2010); Prêmio do Público no Festival de Cinema de Toronto (2010); melhor documentário nos Prêmios Altazor, Pedro Sienna e do Círculo de Críticos de Arte no Chile (2011); Prêmio da Anistia Internacional no Festival de Cinema e Direitos Humanos de San Sebastián, na Espanha
}

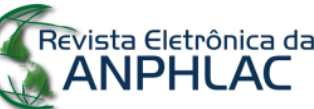

Revista Eletrônica da ANPHLAC, ISSN 1679-1061, № 29, p.127-156, Ago./Dez., 2020.

http://revista.anphlac.org.br 
produção, o cineasta conduz a narrativa a partir da sua própria voz em off (ou seja, ouvimos sua voz, mas não o vemos nas cenas), costurando as suas memórias com as de outros sujeitos que, assim como ele $^{4}$, tiveram suas vidas afetadas pelo golpe e pela ditadura militar, e que carregam nos seus corpos as marcas dos mecanismos repressivos (tortura, mortes, prisões, desaparecimentos, exílio, censura etc.). Ambientado no deserto do Atacama, o filme aproxima as atividades de busca pelo passado realizada pelo próprio diretor e por três grupos que compartilham o deserto: os astrônomos, os arqueólogos e as mulheres que procuram restos de seus familiares desaparecidos durante a ditadura.

Então, o nosso propósito é discutir os problemas suscitados pelos testemunhos contidos em Nostalgia de la Luz (inclusive os do próprio diretor) com alguns dos debates sobre memória e reparação no Chile pós-ditadura até a estreia do filme, ou seja, no período de 1990 a 2010. Assim, buscamos aqui responder às seguintes perguntas: Quais são os usos e sentidos dos testemunhos observáveis no filme? De que forma o documentário pode ensejar debates sobre os vínculos do testemunho com as imagens? Como ele realiza um trabalho com a memória dos seus depoentes? De que maneiras Nostalgia de la Luz pode ser útil para pensarmos as relações da sétima arte, em especial, a sua vertente documental, com as memórias de um "passado que não passa ${ }^{5}$ "?

Nessa parte introdutória, indicaremos uma breve trajetória de Patricio Guzmán. O cineasta iniciou a sua carreira quando estudava no Instituto Fílmico da Universidade Católica

(2011), melhor documentário do ano pela Associação Internacional de Documentários (2011); melhor roteiro no Prêmio Guild em Nova York (2012). Além disso, a obra esteve presente em algumas listas dos mais destacados filmes documentais: a elaborada pelo jornal inglês The Telegraph dos 10 documentários da década e a do British Film Institute que nomeou os 50 melhores documentários de todos os tempos. Por fim, o New York Times incluiu Nostalgia da Luz entre os 20 documentários mais importantes da década.

${ }^{4}$ Logo após o golpe de 1973, Patricio Guzmán foi preso e sofreu ameaças de fuzilamento no Estádio Nacional por duas semanas. Posteriormente, ele e a sua equipe (com exceção do cinegrafista Jorge Müller Silva, sequestrado pela DINA, a polícia política da ditadura chilena) partiram para o exílio. Jorge Müller Silva e a cineasta Carmen Bueno foram presos pela DINA em 29 de novembro de 1974 e até hoje o paradeiro de ambos é desconhecido. Em homenagem aos dois, essa data foi instituída pelo Museu da Memória e dos Direitos Humanos como sendo o Dia do Cinema Chileno.

${ }^{5}$ Segundo Bauer (2017), essa expressão se popularizou após a publicação de Vichy, Un Passé qui ne Passe Pas (1994), em que Henry Rousso analisa a ocupação nazista na França.

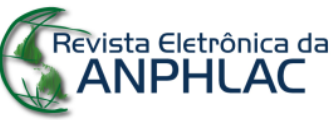

Revista Eletrônica da ANPHLAC, ISSN 1679-1061, № 29, p.127-156, Ago./Dez., 2020. http://revista.anphlac.org.br 
do Chile. O contexto cinematográfico no qual Guzmán produziu seus primeiros filmes se enquadra dentro do Novo Cinema Latino-americano, o NCL ${ }^{6}$.

Em 1966, Guzmán vai para a Espanha dar sequência à sua formação, estudando na Escola Oficial de Cinematografia de Madrid. Retornando ao seu país em 1971, ele realiza o seu primeiro longa-metragem: El Primer $A \tilde{n} o^{7}$ (1972). Segundo informações recolhidas no portal CineChile, posteriormente, Guzmán embarcou em um projeto de realizar uma obra ficcional acerca de um dos líderes da independência chilena, Manuel Rodríguez. Entretanto, o diretor mudou de planos devido aos acirrados confrontos entre a oposição e o governo, especialmente no campo da economia ${ }^{8}$. Nessa atmosfera, em que havia uma urgência de realizar um cinema baseado na coleta de testemunhos produzidos imediatamente aos fatos e que demonstrasse a intensidade desses conflitos, Guzmán e sua equipe abandonam o empreendimento anterior e decidem dar sequência à ideia de realizar uma crônica da Unidade Popular. Deste modo, surge La Respuesta de Octubre (AGUIAR, 2013)

No momento do golpe de 1973, Guzmán estava seguindo o propósito de narrar a cronologia da Unidade Popular ano após ano, filmando um projeto inacabado inicialmente denominado de El Tercer Año. Depois do golpe, o material ainda não montado seguiu para o exílio assim como o próprio cineasta Primeiramente, Guzmán foi para Paris, onde não conseguiu recursos para trabalhar com esse material. Em 1974, a convite de Alfredo Guevara, diretor do Instituto Cubano de Arte e Indústria Cinematográficos (ICAIC), Guzmán se desloca para Cuba (BISPO, 2019). Na ilha caribenha, o cineasta criou um novo filme, a trilogia La

\footnotetext{
${ }^{6}$ O NCL, de acordo com Dávila (2013), propunha como novidade transpor para a sétima arte, especialmente no gênero documental, a necessidade de enfrentamento ao imperialismo. Além disso, havia a pretensão de construir uma identidade cultural a partir das raízes populares de cada país, mas que também pretendia unir toda a América Latina, bem como levar uma "consciência revolucionária" à população. Em outras palavras, o cineasta deveria revestir o seu ofício de uma função militante em prol de uma arte contra a opressão dos países colonizadores, conclamando a libertação do jugo historicamente imposto ao subcontinente.

${ }^{7}$ Esse é um documentário que revelou os feitos do governo Allende durante os seus doze primeiros meses, como a reforma agrária e a estatização de setores econômicos estratégicos, como a extração de cobre, bem como capturar a euforia gerada pela vitória de Unidade Popular.

${ }^{8} \mathrm{Se}$, por um lado, houve uma forte campanha patrocinada pelos sindicatos patronais, em outubro de 1972, para desestabilizar Allende por meio de uma greve de caminhoneiros, por outro, houve tomadas de fábricas organizadas por trabalhadores entusiastas da Unidade Popular para enfrentar o desabastecimento causado pela paralisação comandada pela classe empresarial.
} 
Batalla de Chile ${ }^{9}$, reaproveitando boa parte das filmagens de El Primer Año e La Respuesta de Octubre ${ }^{10}$.

Percebemos, então, que ao retornar ao seu país, Guzmán se propôs realizar uma crônica do governo Allende. Essa tarefa foi progressivamente ganhando outros significados diante das muitas transformações do período. Então, as imagens capturadas por Guzmán e sua equipe ao longo do período Allende adquiriram novos contornos quando reunidas em La Batalla de Chile. Essa trilogia se tornou uma das mais celebradas obras de cineastas chilenos exilados, justamente por manifestar a destruição da possibilidade de um projeto que visava a amplas reformas sociais, bem como denunciar a violência injustificável inerente ao golpe de Estado e à ditadura que se instalou em seguida.

Posteriormente, dos anos 1980 até a metade dos 1990, Guzmán se estabeleceu em Madri e concebeu filmes majoritariamente para a TV espanhola ${ }^{11}$. Em 1997, Guzmán retorna ao seu país depois de mais de duas décadas para realizar Chile, La Memoria Obstinada ${ }^{12}$. A partir dessa película, o diretor passa a produzir na França e lançou documentários que possuem como pano de fundo as dificuldades que o seu país possui para lidar com a memória do seu passado recente e com os traumas dos/as que sofreram (e sofrem) com a violência política e que simbolizam as lutas por reparação e justiça. Nesse sentido, as produções de Guzmán após a

\footnotetext{
${ }^{9}$ Os três filmes que compõem a obra são: La Insurrección de la Burguesía (1975); El Golpe de Estado e El Poder Popular (1979). Assim, a partir de La Batalla de Chile, Patricio Guzmán se tornou um nome ilustre nos circuitos cinematográficos mundo afora (AGUIAR, 2017), sendo que essa trilogia ocupa um lugar de muito destaque na história da produção documentária chilena e latino-americana (VALENZUELA, 2006)

${ }^{10}$ De acordo com Carolina Amaral de Aguiar (2013), não existem mais cópias de La Respuesta de Octubre e o filme se perdeu, sendo totalmente desmontado durante a concepção de La Batalla de Chile.

${ }^{11}$ Esse é o período menos conhecido e estudado da sua carreira e, embora a Unidade Popular e o regime ditatorial de Pinochet estivessem presentes, outros temas foram centrais nessa etapa: a espiritualidade, as resistências culturais e as identidades latino-americanas (DÁVILA, 2017). Nesse espaço, foram lançados os seguintes filmes: La Rosa de los Ventos (1983), a única ficção dentro da obra do diretor que imagina o encontro de um explorador europeu com populações indígenas amazônicas e andinas; En Nombre de Dios (1987), que retrata a atuação da Vicaría de la Solidariedad, um órgão da Igreja Católica chilena que cumpriu um papel importante na luta contra a ditadura; La Cruz del Sul (1992), sobre a religiosidade popular e a Teologia da Libertação e Pueblo En Villo (1995), baseado em um livro sobre o povoado mexicano de San José de Gracia.

${ }^{12}$ Nesse filme, o cineasta se encontra com pessoas entrevistadas por ele na trilogia dos anos 1970, leva um exsegurança pessoal de Allende de volta ao Palácio de La Moneda, e exibe La Batalla de Chile pela primeira vez em sua própria terra natal para estudantes que não viveram o período da Unidade Popular e do golpe militar de 1973. É como se fosse uma "quarta parte" da tríade La Batalla de Chile.
} 
segunda metade dos anos 1990 representam, cada um ao seu modo, a inquietação do cineasta com heranças incômodas da ditadura pinochetista ${ }^{13}$.

\section{Os Testemunhos em Nostalgia de la Luz}

Após demonstrarmos as finalidades do artigo e uma breve trajetória de Patricio Guzmán, neste tópico apresentaremos alguns dos depoimentos contidos no nosso filme objeto. Estes, de alguma maneira, tocam em questões importantes em torno das implicações de um passado cujas marcas traumáticas não se desfizeram, e, além disso, seguem sendo componentes centrais do presente.

Salientamos ainda que não pretendemos executar aqui uma análise propriamente fílmica. Quando houver referências ao enredo, aos aspectos técnicos (ou seja, as escolhas dos planos, ângulos e enquadramentos de câmera, da trilha sonora, dos cortes, da mise-en-scène etc) e a descrição das cenas, tal ação servirá para ilustrar aspectos das expressões das testemunhas do filme, e não a uma apreciação pormenorizada dos recursos narrativos e artifícios da linguagem cinematográfica presentes em Nostalgia de la Luz.

Assim, o primeiro depoimento que trazemos é aquele advindo da cena em que Patricio Guzmán dialoga com o arqueólogo Lautaro Núñez, um dos personagens centrais do documentário, acerca das semelhanças entre as atividades dos astrônomos e dos arqueólogos e como o Atacama favorece o trabalho dos dois profissionais. Em um dado momento, Guzmán, reportando-se ao deserto, afirma que muito embora aquele lugar seja uma porta para o passado, o Chile é um país que menospreza a sua memória. Lautaro responde compartilhando das angústias do cineasta ao afirmar que ainda há muitos mistérios que envolvem a história chilena mais próxima e que é inadmissível o quanto se evita investigar esse passado.

\footnotetext{
${ }^{13}$ Além da já mencionada Chile, La Memoria Obstinada, fazem parte dessa fase da trajetória do diretor mais duas obras: El Caso Pinochet (2001) e Salvador Allende (2004). O primeiro tem como pano de fundo o processo de condenação de Pinochet por crimes contra a humanidade em 1998 e o segundo, lançado logo após a efeméride dos trinta anos do golpe de 1973, resgata memórias do ex-presidente socialista e da própria Unidade Popular, que foi silenciada durante a ditadura. Nessa fase, Guzmán ainda produziu três obras curtas-metragens que privilegiam temáticas bastante introspectivas e de certa forma longe dos debates políticos: Isla de Robinson Crusoé (1999) e Mi Julio Verne (2005), nos quais ele explora a sua ligação com a literatura de ficção científica e de aventura que marcou a sua infância e Madrid (2002), uma viagem pela capital espanhola guiada pela vivência de Guzmán naquela cidade.
} 
O filme nos mostra uma fábrica de salitre que serviu de centro de tortura, o campo de Chacabuco, e também nos apresenta a Luis Henríquez, um ex-prisioneiro desse campo. Guzmán pergunta a Luís se ele já tinha ouvido falar de um grupo de prisioneiros que observava as estrelas. Ele responde que sim e acrescenta que um médico era o professor. Luis diz ainda que ele aprendeu a construir um aparato que possibilitava a observação celeste. $\mathrm{O}$ ex-prisioneiro se lembra dos seus companheiros do cárcere e que o curso de astronomia foi cancelado porque os militares desconfiaram que as estrelas pudessem indicar um caminho para a fuga dos detentos. Para ele, olhar o céu era um ato de liberdade e propiciava a manutenção da sua liberdade interior.

Posteriormente, quem testemunha é Miguel Lawner, a quem Guzmán descreve como "o arquiteto da memória". Miguel participou ativamente da implantação dos programas habitacionais da Unidade Popular e, depois do golpe, passou por cinco centros de detenções, mas conseguiu exílio na Dinamarca e na Alemanha. As suas ilustrações dos campos de concentração se tornaram uma das mais notáveis representações da violência da ditadura. Miguel diz que um arquiteto é capaz de conservar a memória, e que a possibilidade de deixar os seus testemunhos visuais foi um dos motivos que impulsionaram a sua vontade de resistir aos campos de tortura. Esse personagem, filmado provavelmente na sua casa, realiza um ato de memória corporizada na definição de Sadek (2013). Ele caminha, contando os passos e medindo os cômodos, assim como ele fez quando esteve no cárcere, memorizando as dimensões dos recintos da morte e da tortura para desenhá-los à noite, gravá-los em sua memória e de manhã, rasgar os papéis para não levantar suspeitas dos militares.

Destacamos ainda a aparição do terceiro grupo, que faz do deserto o local da investigação do passado. Tratam-se das mulheres de Calama, oriundas da cidade homônima ${ }^{14}$. Uma dessas mulheres, Victoria (Vicky) Saavedra ${ }^{15}$, nos fala sobre os fragmentos do seu irmão.

\footnotetext{
${ }^{14}$ Por meio da voz em off de Guzmán, somos informados que a maioria dessas mulheres procuraram no deserto por 28 anos, de 1974 a 2002, mas que algumas, à época do filme, ainda continuam.

15 Vicky Saavedra, que nasceu em 1943, publicou em 2003, Mi Hermano, Mi Historia, Su Búsqueda Incompleta, livro no qual além de narrar o processo de desaparecimento do seu irmão e como esse fato afetou a sua vida, também cita o sofrimento de outras mulheres da cidade de Calama que anseiam em encontrar os seus desaparecidos.
} 
Vicky enuncia os restos encontrados do seu irmão, Jose, a quem carinhosamente se refere pelo apelido de Pepe: um pé, partes dos dentes, do crânio e da orelha. Vicky também imagina qual teria sido a trajetória do provável tiro que se configuraria como uma hipotética circunstância da morte do seu irmão.

Em sequência, há o relato de Violeta Berríos ${ }^{16}$, outra mulher buscadora, cujo marido, Mário, é um dos muitos desaparecidos da ditadura. Em um dado momento da entrevista, Guzmán menciona a existência dos gigantescos telescópios. A resposta de Violeta ao diretor é carregada de muitas aflições. Ela diz que gostaria que esses instrumentos pudessem também mirar para baixo e identificar os corpos dos desaparecidos. Ela diz ainda que as mulheres de Calama são vistas como "a lepra do Chile", que ninguém responde os seus muitos questionamentos, que ela se sente uma tonta por fazer tantas perguntas cujos esclarecimentos seguem sendo negados e que as mulheres, assim como ela, são um fardo para o seu país. A figura de Violeta Berríos, que na época do documentário possuía aproximadamente 70 anos, ocupa um tempo considerável no documentário. O seu corpo, de aspecto frágil, não é um limite para o seu persistente esforço.

Percebemos que o filme captura o rosto das buscadoras (e dos demais personagens) usando uma câmera fixa. Talvez essa escolha pela ausência de movimentos de câmera se explique por uma intenção de incutir o efeito dramático trazido pelos planos aproximados, como os closes, que é justamente frisar as emoções dos/as entrevistados/as e provocar a identificação do público com os dramas e sentimentos dos/as personagens (LAPOUBLE, 2014). Quando Guzmán filma essas mulheres, vemos os rostos e os seus corpos com planos aproximados e em seguida com planos abertos do Atacama. Dessa maneira, é plausível deduzir que esse é um

\footnotetext{
${ }^{16}$ Extrapolando o que é registrado no filme, no nosso trabalho de pesquisa acerca dessas mulheres buscadoras, encontramos as seguintes informações: Violeta Berríos, nascida em 1938, começou a sua militância depois do golpe de Estado e da detenção do seu marido, filiando-se ao Partido Socialista e à Comisíon Chilena de Derechos Humanos. Ela ajudou a fundar a Agrupacion de los Familiares de Ejecutados y Detenidos Desaparecidos de Calama. A vida de Violeta é sinônima de luta pela verdade e justiça, pois ela vem atuando decisivamente nas iniciativas de valorização e preservação das memórias das vítimas. Violeta recebeu, em 2016, como forma de reconhecimento da importância da sua trajetória pela defesa dos direitos humanos, o Prêmio Nacional de Direitos humanos concedido pelo Instituto Nacional de Direitos Humanos do Chile.
}

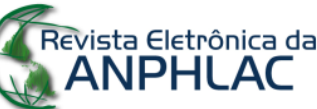

Revista Eletrônica da ANPHLAC, ISSN 1679-1061, № 29, p.127-156, Ago./Dez., 2020.

http://revista.anphlac.org.br 
artifício utilizado pelo diretor para corroborar o quanto a tarefa das mulheres é árdua, pois ocorre em um espaço gigantesco.

Nos minutos derradeiros do filme, Guzmán dedica-se a vestígios de outras temporalidades, afastando-se temporariamente da abordagem sobre a ditadura. Então, em um primeiro momento dessa parte final da película, o diretor refere-se aos povos originários do deserto, mostrando seixos trazidos pelo mar e recolhidos por essas civilizações, que, de acordo com a narração do diretor, possuíam saberes sobre os corpos celestes e faziam seus enterros à noite, sob a luz das estrelas.

Guzmán nos diz ainda que os cientistas (provavelmente arqueólogos) coletaram os restos desses homens e mulheres antigos e os depositaram cuidadosamente. O cenário se desloca do Atacama para salas destinadas à conservação dos ossos humanos milenares, e vemos uma múmia. Em seguida, em um museu, surge a ossada de uma baleia e o diretor relata que a sua mãe o levava para visitar esse esqueleto durante a sua infância e se perguntava se assim como as populações originárias e as baleias, os restos dos desaparecidos um dia terão direito a algum monumento, se terão sepultura e se serão identificados e catalogados.

Na parte final de Nostalgia de la Luz, há outro destaque para a astronomia. Guzmán nos apresenta uma jovem astrônoma, Valentina Rodríguez, que, ao longo da entrevista, narra que trabalhar com essa ciência a ajuda a lidar com os traumas causados pela perda dos seus pais, desaparecidos pela ditadura. O tom de voz de Valentina segue calmo, a despeito do seu testemunho ser marcado por temas espinhosos, como a perda dos pais e a decisão dolorosa tomada pelos seus avós (revelar, sob ameaça, o paradeiro dos pais dela). À medida em que ela relata, percebemos que o trabalho na astronomia juntamente ao próprio ato de narrar essas experiências tornam-se elementos terapêuticos diante da dor provocada pela ausência dos pais e, ao mesmo tempo, permitem que Valentina possa, mesmo com essa perda, atribuir outras dimensões à sua vida. No final, ela segura o seu bebê, que, segundo ela, nasceu "sem um defeito de fabricação", isto é, sem ser filho de presos políticos.

Por fim, o documentário se encerra a partir de um plano detalhe de bolinhas de gude e da última cena (uma tomada aérea de Santiago). O diretor tece algumas considerações: os infortúnios dos chilenos são diminutos diante da infinidade do cosmo, mas se tais adversidades 
forem colocadas sobre uma mesa, elas parecerão ter as dimensões de uma galáxia. Ele afirma que durante a produção de Nostalgia de la Luz, deparou-se com as bolinhas de gude, esses objetos que propiciaram a magia de guardar no bolso um universo inteiro. Guzmán, na sequência, então, quando a capital chilena é registrada do alto, profere, em tom solene, que a memória exerce um poder de atração tão forte quanto a gravidade e que quem a possui vive em meio ao delicado presente, e já quem não a possui, seja em que tempo for, é simplesmente inábil para viver.

\section{O Trabalho da Memória em Nostalgia de la Luz}

De acordo com Seligmann-Silva (2005; 2008), o testemunho tenta reunir fragmentos de um passado que não passa, ou seja, um passado que se faz presente, seja porque a testemunha verbaliza no agora, seja porque se refere a um passado que sempre vem à tona. Assim, conforme diz Seligmann-Silva (2005), se na América Latina há uma “literatura do testemunho" ${ }^{17}$ ", também há um "cinema do testemunho", do qual Patricio Guzmán é um dos mais extraordinários representantes ${ }^{18}$.

Outra característica importante do testemunho é a sua vinculação às especificidades de cada região: enquanto na Europa o conceito costuma versar sobre os sobreviventes da Shoah e da Segunda Guerra, na América Latina ele é associado às últimas ditaduras militares. Todavia,

\footnotetext{
${ }^{17}$ Segundo Basile e Chiani (2020), parece haver um consenso que esse tipo de relato na região se consolidou com a ajuda dos aparatos culturais da Revolução Cubana, que fomentaram a publicação de obras como La Guerra de Guerrillas (1960), de Ernesto Che Guevara e Biografía de Un Cimarrón (1966) de Miguel Barnet. A isso, soma-se a criação da categoria de "testemunho" dentro do prêmio literário oferecido pela Casa de las Américas. Assim, se na década de 1960, o testemunho atendia às lutas por transformações sociais, duas décadas mais tarde, esse tipo de produção, amplamente incorporada pelas organizações de direitos humanos, passou a ser a expressão, por excelência, das subjetividades de quem sofreu com o terror de Estado. A partir da década de 1980, a matriz revolucionária do testemunho latino-americano foi substituída pela denúncia das enormes violações de direitos humanos executadas pelas ditaduras militares. O vocabulário se alterou: da dicotomia povo/oligarquia ou proletariado/burguesia passou-se a falar em vítimas/algozes.

${ }^{18}$ Embora as obras do Patricio Guzmán sejam célebres nesse cinema de teor testemunhal, é preciso se atentar para a relevância de filmes, ficcionais e documentais, de outros/as produtores/as chilenos/as que também abordam a experiência da Unidade Popular, do golpe de 1973 e a posterior ditadura. Nesse sentido, destacamos as ficções Machuca (2004), de Andrés Wood, Dawson lsla 10 (2009) e Allende En Su Laberinto (2014), de Miguel Littín, Tony Manero (2008), Post Mortem (2010) e No (2012), de Pablo Larraín. E em relação aos documentários, além dos de autoria de Guzmán, sublinhamos os seguintes: La Flaca Alejandra (1994) e Calle Santa Fe (2007), de Carmen Castillo; Mi Vida con Carlos (2010), de German Berger, El Eco de Las Canciones (2010), de Antonia Rossi, El Edificio de Los Chilenos (2010), de Macarena Aguiló e El Diario de Augustín (2008) de Ignácio Agüero.
} 
o termo vem sendo utilizado para se referir a outras temáticas e sujeitos: feminicídio, a população negra, grupos LGBTs. massacres étnicos ${ }^{19}$, migrações forçadas etc. (BASILE, CHIANI, 2020; SELIGMANN-SILVA, 2005)

Cortés (2017) argumenta que as dificuldades para determinar se o testemunho é um gênero que pertence a um domínio específico (a literatura ou o jornalismo) ou se ele é híbrido se vinculam à sua identificação e absorção com outros tipos de discurso: a autobiografia, a crônica, o diário, o ensaio e até mesmo em obras ficcionais, como novelas ${ }^{20}$. Todavia, Sanchéz (2020) destaca que por mais que se observem interpretações díspares sobre o que essa forma discursiva seria, há um consenso de que o testemunho apresenta um elemento que extrapola as tentativas de teorizá-lo. Trata-se da sua dimensão política indubitável, já que ele serve à conservação de memórias soterradas e à denúncia de atrocidades. O testemunho denota uma premissa que salta aos olhos: é um gênero que se localiza em fronteiras interdisciplinares e possui implicações políticas e jurídicas. (CÓRTEZ, 2017)

Márcio Seligmann-Silva (2008) nos oferece ainda reflexões profícuas: o testemunho seria uma atividade terapêutica para quem sofreu, uma vez que impulsiona uma necessidade de se compartilhar os traumas, gerando as condições para a reintegração aos outros e à comunidade. A narrativa testemunhal carrega principalmente um sentido de fazer com que o sobrevivente renasça, começando o seu religamento com o mundo, e reelabore o seu próprio passado. Dessa maneira, percebemos essas dimensões nos testemunhos apresentados em Nostalgia de la Luz. Os depoimentos presentes no nosso filme-objeto são muito mais que meros componentes de um documentário, são também tentativas de se revisitar as próprias

\footnotetext{
${ }^{19}$ Teresa Basile e Miriam Chiani (2020) assinalam que alguns estudos recentes sobre o testemunho, elaborando o passado sob o ponto de vista dos "vencidos", recuam a períodos anteriores aos anos 1960 e 1970. Esses trabalhos propõem uma "genealogia latino-americana" em torno das noções de extermínio e aniquilação. Dessa forma, essa perspectiva sugere que tanto colonizadores europeus quanto os Estados nacionais no século XIX foram responsáveis pelo genocídio das populações originárias. No caso da Argentina, as autoras reportam-se à chamada "conquista do deserto", liderada em 1879 pelo general Julio Argentino Roca para "pacificar" e "civilizar" o sul do país. A respeito deste episódio, David Viñas afirma que os indígenas foram os primeiros a sofrerem com as práticas de desaparecimento.

${ }^{20}$ Segundo Basile e Chiani (2020), a "família testemunhal" agrupa subgêneros semelhantes, tais como os relatos de tons etnológicos e autobiográficos e os textos jornalísticos.
}

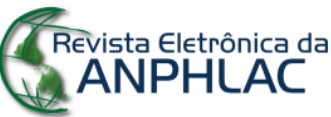

Revista Eletrônica da ANPHLAC, ISSN 1679-1061, № 29, p.127-156, Ago./Dez., 2020. http://revista.anphlac.org.br 
experiências, de seguir resistindo ao silêncio e de dividir o drama com os outros e, assim, reconstruir e fortalecer os laços afetivos quebrados pela violência.

Essa função contida no testemunho aparece de modo mais nítido em algumas cenas do documentário. A primeira delas é a reservada à jovem astrônoma Valentina Rodriguez: a astronomia serve como uma espécie de terapia para se lidar com o trauma do desaparecimento dos pais. A segunda é aquela na qual vemos Miguel e o seus desenhos das prisões.

Por fim, há outra dimensão desse termo que é possível destacar: todo testemunho possui uma condição de ser único ${ }^{21}$, a sua mensagem é absolutamente singular (SELIGMANNSILVA, 2008) e revela diferentes maneiras pelas quais os sujeitos vivenciaram determinados períodos históricos tendo em vista algumas especificidades, entre outras, de gênero, raça, classe, origem regional.

É necessário frisar, então, que o processo de destruição da dimensão subjetiva, por meio da tortura, do desterro ou do desaparecimento, constituiu uma operação estratégica na implementação do terror, pois a violência do Estado tinha o objetivo de impor sérios limites para a representação dos acontecimentos e até mesmo eliminar as provas, inclusive testemunhais, das truculências perpetradas. O testemunho, então, tem um significado muito importante na luta contra a política de eliminação da história e das subjetividades. (BAUER, 2017) Nesse sentido, uma das sequências mais impressionantes de Nostalgia de la Luz é a composta pelos relatos de Violeta Berríos, especialmente o momento em que ela afirma que as mulheres de Calama, segundo parte da sociedade, são a "lepra do Chile". Inferimos que para Violeta, talvez a maior aflição não se origina de relembrar o desaparecimento do seu marido e da dor permanente de perder o seu ente querido, mas da atitude de uma parcela da sociedade chilena de que enxerga como "revanchismo" as lutas de quem foi atingido pelas estratégias da

${ }^{21}$ É interessante notar que o próprio Patricio Guzmán também faz referência a essa condição do testemunho, articulando-a ao cinema documental: "Nos documentários, os personagens [...] articulam a história, expõem as ideias e concretizam o tema [...] Talvez sejam os agentes narrativos mais inevitáveis. Sua escolha, portanto, é chave. Não temos apenas que buscar os indivíduos que conhecem mais o tema, mas os seus melhores expositores, os que sejam capazes de transmitir uma experiência envolvente, oferecendo um testemunho pouco comum". (GUZMÁN, 2017, p.58) 
perversidade da ditadura e teve o seu corpo e a sua trajetória pessoal completamente alterados pelas situações-limite.

Outrossim, Elizabeth Jelin (2002) indica que a memória, mesmo aquela que foi tolhida por décadas ou restrita ao mundo privado, é capaz de perdurar sempre que há um cenário no qual os atores sociais (re)significam esse passado com vistas à elaboração de um presente e de um futuro com outros rumos possíveis. Há momentos, como os períodos transicionais, nos quais surgem condições propícias para que narrativas que estiveram ocultas por muito tempo possam irromper.

Entretanto, a memória não somente retém, mas suprime informações e privilegia outras. Dessa forma, pode-se afirmar que na memória também há esquecimento. Lembrar e esquecer, então, não são antônimos, mas ações que compõem toda e qualquer memória. Isto implica dizer que os processos da memória são seletivos e, assim, não se pode armazenar e nem olvidar tudo. Por conseguinte, se recordar e esquecer não são ações dicotômicas, é viável pensar que o antônimo de olvido não é memória, mas sim justiça (YERUSHALMI, 1989, apud, JELIN, 2002, p.137).

Inclusive, se existe o direito (e o dever) de se lembrar, há também o direito ao esquecimento. Todorov (2000) disserta sobre esse direito e diz que embora os indivíduos e grupos não sejam independentes do passado, fazê-los recordar frequentemente de momentos mais angustiantes e dolorosos é um ato demasiadamente cruel, e, portanto, o esquecimento se torna um direito legítimo. Jeanne Marie Gagnebin (2010), nessa mesma linha, apoiando-se na filosofia de Nietzsche, diz que o ato de esquecer possui aspectos positivos na medida em que permite estar no presente sem o fardo incômodo do passado com mágoas ou ressentimentos. Embora o esquecimento apresente essa condição benéfica, quando ele é imposto e é realizado com o intuito de ignorar e apagar as marcas de crimes atrozes, deixa de ser uma opção válida diante da necessidade terapêutica de se viver bem o presente.

Então, se sabemos que o esquecimento não se opõe à memória, como podemos entender o que de fato seria a desmemória, outro conceito que surge constantemente nesse debate? Para tentar responder, recorremos aos argumentos de Enrique Serra Padrós (2004), que, à primeira vista, podem parecer uma obviedade, mas que são importantes para a compreensão apurada dos 
possíveis significados de desmemória. Não é possível se esquecer daquilo que não se conhece, uma vez que só se pode organizar, sistematizar, enfatizar (e até mesmo suprimir) aquilo que é da ordem do experiencial. Sendo assim, a desmemória, segundo o autor, mais que um equivalente de apagamento ou esquecimento, relaciona-se mais com a possibilidade de não haver condições para se recordar para consequentemente depois se esquecer. A desmemória pode ser entendida não como um sinônimo de esquecimento, mas como um conjunto de estratégias caracterizadas pela impossibilidade ou pela enorme dificuldade de investigar o que ocorreu, o que resulta na inexistência ou na existência muito precária de informações sobre um determinado passado.

Nesse sentido, a desmemória é uma importante chave de leitura daquelas que são na nossa interpretação, algumas das passagens mais emblemáticas de Nostalgia da Luz. A primeira consiste no relato de Lautaro Núñez. O arqueólogo divide a aflição de Guzmán acerca do escamoteamento do passado próximo no Chile:

É um paradoxo. Nosso passado mais próximo, nós o encapsulamos. É um enorme paradoxo. Escute...Não sabemos praticamente nada sobre o século XIX. Quantos segredos guardamos sobre o século XIX? Nunca dissemos claramente por que marginalizamos nossos índios. É quase um segredo de Estado [...] Nossa história mais próxima, nós mantivemos escondida. Nós a mascaramos. É um absurdo: hesitamos em nos aproximar dessa história próxima [...] Isso, caro amigo, não serve, não serve a ninguém, nem à direita, nem ao centro, nem à esquerda.

Já a segunda é parte de um depoimento de Violeta Berrios, que, por meio de um tom nitidamente comovente, verbaliza o seguinte:

\begin{abstract}
Se precisar continuar, continuarei, apesar de ter muitas dúvidas, muitas perguntas que não posso responder, porque dizem que os desenterraram, puseram em sacos, os levaram e lançaram ao mar. A dúvida é: lançaram mesmo ao mar? E se os jogaram aqui nas montanhas? À essa altura da minha vida, tenho setenta anos, custo a acreditar nas coisas. Ou seja, eles me ensinaram a não acreditar [...]. Às vezes pareço maluca, porque faço perguntas e mais perguntas e ninguém pode responder o que eu quero.
\end{abstract}

Percebemos então que Violeta revela a sua perplexidade diante da falta de conhecimento fático sobre os desaparecidos. Ela levanta suspeitas sobre o que teria acontecido com os ausentes, pois as respostas não são adequadamente elucidativas a respeito do tema. Quando Violeta afirma que para ela é muito difícil confiar naquilo que "eles" (os representantes do Estado) dizem é porque mesmo tendo se passado vinte anos do retorno democrático, a grande 
maioria dos questionamentos que ela e as outras mulheres de Calama fazem segue sem resoluções.

Nesse ponto, trazemos as considerações de Todorov (2000), para quem é preciso distinguir os usos da memória. Para o autor, uma coletividade pode lidar com um acontecimento de duas formas: a literal, que o enxerga como um caso único, cuja análise não pode extrapolar a si mesmo; e a exemplar, que embora não negue a singularidade do fato, traduz as experiências ligadas a ele em demandas mais generalizadas e, assim, partindo da analogia, o passado se torna um exemplo, isto é, um princípio de ação para o presente e uma perspectiva que permite compreender outras situações.

Segundo Elizabeth Jelin (2002), então, a memória literal faz com que se leve à noção de glorificação de determinadas vítimas, tratadas como “privilegiadas". Por outro lado, a memória exemplar é capaz de superar a dor, transferir a recordação do âmbito privado ao mundo público e também pode retirar do passado algumas lições que se transformam em referências para se intervir no tempo corrente.

A partir da noção de "empreendedores sociais", cunhada por Howard Becker para referir-se às práticas de agentes que mobilizam as suas energias em função de uma causa, Jelin (2002) elabora o termo de "empreendedores da memória", a exemplo das associações de direitos humanos e de vítimas (assim como as mulheres de Calama). A notoriedade desses sujeitos é central, pois sem as suas lutas não haveria a construção ou a ressignificação de espaços destinados ao combate do olvido de inaceitáveis afrontas à dignidade humana e até mesmo a produção de itens culturais, como filmes, exposições, romances, peças de teatro, espetáculos de dança e obras acadêmicas.

As frentes de atuação desses grupos são diversas: podem tentar mudar o sentido da história oficial ou hegemônica, levar até o espaço público relatos que estiveram ocultos ou censurados, reivindicar reparações materiais, como as indenizações. Embora essa reparação pecuniária esteja longe de compensar os danos, pelo menos sinalizam o reconhecimento das vítimas por parte do Estado. Esses grupos também exigem que se faça justiça no seu aspecto simbólico por meio da criação de lugares de memória, a exemplo de museus e monumentos. Deste modo, o conceito de "empreendedores de memória" implica a apropriação de uma 
memória exemplar, voltada à concretização de projetos que visam se posicionar no presente e projetar cenários futuros.

Recorremos aos argumentos de Jeanne Marie Gagnebin (2006) acerca dos usos da memória. Essa obrigação de se lembrar sempre, a necessidade ética de se combater todo tipo de esquecimento, pode ser problemática, uma vez que pode desembocar em uma comemoração superficial que serve às narrativas interessadas na manutenção da realidade. Então, seria preciso diferenciar duas ações mnemônicas: a comemoração, referente a cultos religiosos ou à história oficial, e a rememoração, referente às oportunidades de alterar as condições do tempo corrente. A rememoração seria, então, “(...) uma atenção precisa ao presente [...] pois não se trata somente de não se esquecer do passado, mas também de agir sobre o presente. A fidelidade ao passado, não sendo um fim em si, visa à transformação do presente.” (GAGNEBIN, 2006, p.55)

Na nossa interpretação, uma das práticas memorialísticas que vemos em Nostalgia de la Luz é justamente a rememoração. Tanto Patricio Guzmán quanto os seus/as entrevistados mais que mencionarem os problemas do passado, mais que acentuarem o imperativo moral de preservar as lembranças do horror para que não haja a sua repetição, também afirmam possibilidades de se intervir no presente, verbalizam posições críticas ao status quo, expõem uma ânsia para que as políticas estatais e a atitude de parte da sociedade em relação ao passado traumático sejam muito mais sensíveis às demandas dos "empreendedores da memória". Mesmo que seus testemunhos não sejam tão explícitos, eles revelam a aspiração de fazer com que a conjuntura do instante em que eles narram mude substancialmente e que o porvir seja diferente.

Trazendo as contribuições de Isabel Piper Shafir (2015), pode-se afirmar que a memória não possui como único alvo o já decorrido, uma vez que ela guarda expectativas em relação ao tempo corrente e ao tempo vindouro e apresenta um poder simbólico, que produz imaginários com o poder de se converter em fonte para resistências e impulsionar transformações na realidade. Assim, a memória acaba se constituindo em um dos elementos fulcrais da motivação e da justificativa da atuação política de diversos grupos e sujeitos, que, de tempos em tempos, ganham relevância no espaço público. A propriedade de lembrar articula distintas 
temporalidades, isto é, a memória se desloca entre o que já foi consumado e aquilo que ainda não se concretizou (RICHARD, 2010).

Nesse sentido, para Jelin (2002), a memória implica um "trabalho", já que é muito possível incorporá-la às tarefas que geram possíveis modificações no mundo social. Desse modo, conforme indicam Franco e Levín (2007), a memória é uma categoria dinâmica: não apenas guarda informações, mas é também um campo de disputas em torno dos significados do passado; é uma matéria-prima da intervenção nos rumos do presente e do futuro e é capaz de entrelaçar as experiências pessoais e coletivas.

Por conseguinte, discutiremos alguns dos muitos momentos de Nostalgia de la Luz que canalizam esse aspecto da memória enquanto um “trabalho". O primeiro deles é o seguinte: é aquele quando Guzmán evoca uma atividade frequente na sua infância: as visitas a um museu onde havia o esqueleto de uma baleia. $\mathrm{O}$ filme nos mostra até um arquivo no qual há uma múmia. Guzmán diz que há outros ossos, os restos dos desaparecidos, mas que não têm nome, identidade ou um lugar reservado em monumento ou em museu. $\mathrm{O}$ cineasta, então, quando compara os três restos (os da baleia, os dos povos originários e os dos vitimados pelo autoritarismo), revelando a discrepância de visibilidade entre eles, reivindica que estes últimos tenham as suas questões e informações devidamente elucidadas. O cineasta, ao nos lembrar da necessidade de não deixar a ausência de respostas em relação aos desaparecidos cair no ostracismo, não apenas menciona pontos mal resolvidos do passado, mas exige que mesmo com o passar do tempo, a investigação do paradeiro dos desaparecidos da ditadura não cesse.

O segundo é retirado do testemunho de Violeta Berríos, que ocupa quase 5 minutos da película, entre 58 minutos e 53 segundos e 1 hora, 3 minutos e 42 segundos. Ela narra que embora a sua saúde não seja a mesma de anos atrás, a esperança alimenta a continuidade das idas ao Atacama. $\mathrm{O}$ dever de fazer jus à memória do seu marido e também a de familiares das suas companheiras impede o abandono da procura. Violeta narra que foi ao deserto com Vicky tantas vezes e mesmo que em determinados instantes elas se sentissem frustradas, ambas retornavam com ainda mais determinação. Ou seja, Violeta e as outras mulheres fazem da memória um elemento que justificava a continuidade da labuta apesar do desamparo de parte da população e do Estado. Em um trecho desse depoimento, Violeta diz que alguns poderão questionar a 
razão das mulheres de Calama buscarem ossos. Ela responde que, embora tivesse encontrado a mandíbula de Mario, ela se recusou a aceitar, porque se o levaram inteiro, ela quer o corpo do seu marido também na íntegra:

\begin{abstract}
Não tenho a força de vinte anos atrás nem a saúde de vinte anos atrás [...], mas a esperança dá muita força. Foram tantas as vezes que fui com Vicky ao deserto...Tantas, tantas. Fomos com tantas esperanças e voltamos com a cabeça baixa. Mas nos levantamos, nos sacudimos e partimos no dia seguinte com mais esperança, mais vontade, mais desejo de encontrá-los...Algumas pessoas perguntarão: 'para que querem esses ossos?' ...Eu os quero, os quero muito e muitas outras mulheres os querem. Quando me disseram que havia a mandíbula de Mario, eu não a quis [...]. Eu o quero inteiro, eles o levaram inteiro, não quero um pedaço dele. E não apenas dele, mas de todos.
\end{abstract}

Uma sequência anterior, compreendida entre 48 minutos e 33 segundos até o minuto 51, é aquela em que o astrônomo Gaspar Galaz, mesmo não tendo sofrido na própria pele as marcas da repressão (pelo menos é assim que o filme o retrata), se sensibiliza com as buscadoras que a não se deixam abater e preservaram a despeito da desmedida consternação:

\begin{abstract}
Se fizer uma comparação, embora não sejam comparáveis, mas é parecido com o que faz um astrônomo, com uma diferença: nós podemos dormir tranquilos depois de cada noite de observação olhando para o passado [...]. Às vezes dormimos um pouco mal, pois o ar é muito seco, mas no dia seguinte, voltamos ao passado sem conflito, sem nada. Mas essas mulheres não vão dormir depois de procurar restos, procurando um passado que não encontram. Nunca vão dormir bem enquanto não encontrarem. Acho que é essa a grande diferença. Ou seja, não é comparável [...] O curioso é que a sociedade deveria entender bem mais as mulheres que fazem isso do que os astrônomos. Mas acontece o contrário [...] Dizem: 'Já passou tanto tempo, já chega!’. Eu acho que isso não é possível. E enquanto elas não encontrarem seus familiares, nunca terão paz [...]. Eu imaginaria meu pai ou minha mãe no espaço perdido em algum lugar da galáxia, e eu estaria procurando-os com o telescópio. A angústia seria enorme, o espaço é tão grande que seria quase impossível encontrá-los. Acho que é o mesmo para essas mulheres. O deserto de Atacama é gigantesco!"
\end{abstract}

Gaspar, então, se compadece dos tormentos das mulheres de Calama, imaginando como seria se um familiar seu fosse um desaparecido no meio das galáxias. A dificuldade para encontrá-los seria descomunal. E esse sentimento de uma pesquisa extremamente fatigante é o que acomete essas mulheres todos os dias, pois o Atacama, metaforicamente, é palco de uma busca por fragmentos de corpos humanos passível de ser comparada em alguma medida à identificação de corpos celestes no espaço sideral sem fim. 
Todavia, Gaspar, em um gesto de empatia genuína com as mulheres de Calama, diz que enquanto um astrônomo lida com um passado desafiador, mas que não afeta o sono e nem gera perturbações morais, as mulheres buscadoras possuem uma relação com um passado que evoca perdas pessoais causadas pela repressão, que simboliza dores renuentes a passar, que continuará enquanto todos os restos dos/as desaparecidos/as não forem localizados e identificados. Por isso, Gaspar exprime uma crítica incisiva à sociedade, que oferece muito mais apoio e admira muito mais os astrônomos que essas mulheres.

Gostaríamos de explorar um ponto que chama muito a atenção nos depoimentos de Guzmán, Violeta e Gaspar, listados acima: o destaque conferido à necessidade de se descobrir evidências, mesmo que aparentemente ínfimas. Assim, interpretamos que no filme há constantes menções aos restos dos/as desaparecidos e outras marcas dessa situação limite, seja no testemunho dos personagens, seja em alguns closes: as mãos de Vicky, que seguram os ossos do seu irmão, os desenhos de Miguel, a parede com os nomes dos companheiros de Luis em Chacabuco e as fotografias de vítimas. Por que Nostalgia de la Luz enfatiza tanto esses indícios? Imaginamos que uma possível resposta reside nos argumentos de Ginzburg (2012): o rastro ajuda a reelaborar os laços sociais e a compreender amplamente um determinado passado.

\begin{abstract}
A reflexão sobre o rastro representa um confronto sério e qualificado com as políticas de esquecimento. A partir de elementos residuais, é possível construir uma história contra os agentes de destruição [...] A categoria do rastro inspira a reconstrução constante do ato de narrar, conferindo ao detalhe, ao resto, um papel constitutivo do passado. Contra os discursos [...] do autoritarismo, irrompe a linguagem [...] que permite realizar saltos no processo de conhecimento [...]. Cada rastro, cada ruína, cada fragmento pode trazer em si um potencial de conhecimento do passado (GINZBURG, 2012, p. 115)
\end{abstract}

Os vestígios que Nostalgia de la Luz põe em tela (os próprios testemunhos, os ossos dos desaparecidos, as ruínas de Chacabuco, as ilustrações de Miguel etc.) constituem uma poderosa contraposição às operações de esquecimento proposital dos perpetradores. Eles servem como indícios que reconstituem experiências históricas, abrindo possibilidades frutíferas de se conhecer novos aspectos do passado partindo de uma dimensão subjetiva e representam também uma forte contraposição às tentativas de omitir ou invalidar os debates acerca da persistência dos traumas. 
Vimos, então, que a recordação é umas das principais razões (senão a principal) pelas quais os indivíduos e/ou organizações se inserem nos debates da atualidade. Assim, segundo Sarlo (2007, p.61), “(...) os que lembram não estão afastados da luta política contemporânea; pelo contrário, têm fortes e legítimas razões para participar dela”. E, nesse sentido, o tema dos desaparecidos não é de fácil solução, tendo em vista que requer a responsabilidade criminal, moral e política dos atos de violência. Esse tema, portanto, une o presente das transições ao das ditaduras, do qual se deveria esquivar em nome do "progresso" e da estabilidade.

Dessa forma, contrariamente ao objetivo dos governos transicionais, isto é, a aposta no silenciamento, houve pessoas que se recusaram a esquecer dos crimes contra a humanidade praticados pelo Estado (BAUER, 2014). Entre elas, destacamos principalmente os familiares dos mortos e desaparecidos, que demonstram uma extraordinária capacidade de recordação. Os relatos de Violeta Berríos e Vicky Saavedra, duas das mulheres que vasculham o Atacama, demonstram que, apesar de se mostrar demasiadamente longa e muitas vezes frustrante, a busca por restos mortais de seus familiares persistem. Os depoimentos dos personagens de Nostalgia de la Luz demonstram que os aspectos afetivos estão diretamente ligados às ações políticas. A necessidade de se lembrar dos entes queridos se amplia para além da esfera familiar, atingindo o espaço público e se tornando um alerta para toda a sociedade: o silenciamento das experiências traumáticas geradas pela ditadura e das suas incômodas consequências para a coletividade precisa ser seguidamente coibido.

Segundo Dorfman (2003), a reconciliação ${ }^{22}$ anunciada pelos distintos governos transicionais no Chile será impraticável e vazia se a imunidade seguir como norma. Se os problemas herdados do regime pinochetista continuarem não sendo esmiuçados e confrontados de maneira tímida, e se os distintos governos insistirem em olhar adiante sem que a justiça no que se refere aos direitos humanos tenha sido feita, a reconciliação não passará de uma vaga promessa:

\footnotetext{
${ }^{22}$ Desse modo, quiçá seja oportuno destacar a contribuição de Jeanne Marie Gagnebin (2010): a memória das vítimas questiona fortemente aquilo que a autora denominou de "reconciliação extorquida"; isto é, aquela baseada na interdição do debate sobre o passado ditatorial, cujas práticas ainda seguem fazendo parte do presente, sem que haja possibilidades imediatas para a sua dissolução. De acordo com Elizabeth Lira (2000), há uma tendência de se associar a paz social à "reconciliação", entendida como sendo um processo no qual se considera um conflito por encerrado, suprimindo, deliberadamente, o que é antagônico ao discurso oficial.
}

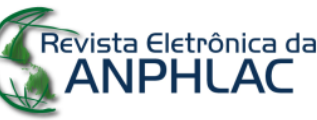

Revista Eletrônica da ANPHLAC, ISSN 1679-1061, № 29, p.127-156, Ago./Dez., 2020. http://revista.anphlac.org.br 
Investigar o horror, mergulhar nos desmandos do passado, levar a julgamento funcionários do regime anterior, tudo isso, dizem que apenas desvia a atenção da tarefa mais urgente no momento, da necessidade premente de alcançar a reconciliação nacional. No caso do Chile, parece que os novos líderes democráticos não se deram conta de que é impossível obter essa reconciliação mítica ignorando a dor de boa parte de uma nação dividida, impossível restaurar o respeito às leis partindo da invulnerabilidade dos que cometeram crimes atrozes, e de que a condição para construir um futuro comum é justamente examinar o passado que nos fratura. (DORFMAN, 2003, p.186)

Então, cabe lembrar que há necessidade de um processo de enfrentamento do passado para que haja uma reparação aceitável, uma vez que as transições democráticas não se resumem somente a indenizações financeiras e retratações simbólicas, mas que assumem também uma dimensão coletiva que se relaciona com a própria construção da democracia. Deste modo, entendemos que “(...) ao contrário do que supunha a argumentação de que a promoção da Justiça poderia ser um fator de desestabilidade política e social [...] está provado que a impunidade corrói as bases do Estado de Direito e afeta a essência da democracia.” (BAUER, 2014, p.183).

\section{O Trauma na Tela: Nostalgia de la Luz como Documentário de Memória e Testemunho Fílmico}

Sobre os vínculos da arte, especialmente as imagéticas, com as narrativas testemunhais, encontramos uma chave de leitura frutífera. Para Didi-Huberman (2011), as imagens não somente são reflexos de dadas recordações, mas também são capazes de produzir memória e de interligar tempos e experiências heterogêneas sob uma montagem poética, e não cronológica.

Trazendo as contribuições de Andreas Huyssen (2009) quanto ao antigo conflito estabelecido entre a retórica das palavras e o poder das imagens, salienta-se que as primeiras têm sido privilegiadas. Deste modo, se por um lado a linguagem escrita tem sido associada à temporalidade, à objetividade e à consciência crítica, por outro, a imagem tem sido associada ao espaço, a significados superficiais, à fragilidade e à falta de confiança. Entretanto, essa separação binária impede que a relação entre esses elementos seja compreendida como de fato ela é, isto é, mútua. Devemos, portanto, reconhecer que imagem e palavra, bem como memória e história, são complementares e se entrelaçam, além de se provocarem de forma recíproca. 
Georges Didi-Huberman (2011) se reporta a Walter Benjamin, argumentando que o filósofo alemão foi responsável por uma revolução: o passado já não era mais um "fato objetivo", mas uma instância composta de memórias. O movimento de recordação, estabelecido no presente, permite a feitura do conhecimento histórico. Assim, para Benjamin, a escrita da história não se faz sem os debates sobre os vestígios da memória "dos vencidos" e interpretar a história à contrapelo significa deparar-se com a sua faceta catastrófica. (BENJAMIN, 2012 apud SELIGMANN-SILVA, 2013).

Para Ana María Amar Sanchéz (2020), segundo a tradição do pensamento de Walter Benjamin, se a marcha do tempo promove um inexorável esquecimento, o relato do vitimado é fulcral para se revelar faces ocultas e silenciadas do passado. Assim, a atenção à palavra da vítima pode ser o começo de um algum tipo de reparação. Aqui, nesse ponto, essa autora cita Philipe Mesnard, para quem questões éticas estão intrinsecamente ligadas às linguagens que representam a violência, e por isso talvez não se possa pensar a ética sem que se recorra às vozes presentes nas produções artísticas.

Nesse sentido, Seligmann-Silva (2013) argumenta que a arte possui a habilidade de recuperar os rastros do horror. A arte é um suporte de memória capaz de inscrever o tema da violência no espaço público mesmo com lacunas ou informações precárias. Além de apresentar a função de denúncia, as produções artísticas podem servir para que se possa fazer o luto, bem como para elaborar o trauma. A arte, por meio da ênfase conferida dos resquícios de atos hediondos que são denegados, se compromete com a verdade e justiça em relação a fatos sensíveis que constantemente são escamoteados.

Independentemente do gênero, os filmes também podem ser lidos enquanto "atos de memória" que, para Richard (2010), inscrevem os testemunhos no contexto de sociedades nas quais aconteceram catástrofes massivas. Tais atos possuem a virtude de reavivar aquilo que foi escondido pelos agentes da aniquilação, corroborando a obrigação ética do "Nunca Mais". 23

\footnotetext{
${ }^{23}$ Se a memória se constitui enquanto um campo de luta política, frequentemente esses embates são projetados com o intuito de combater o esquecimento por meio de uma condição pedagógica: a lembrança evita a reincidência dos tantos processos históricos dolorosos que marcaram o século XX. A partir dessa premissa que confere ao lembrar a capacidade de impedir a ocorrência de novos autoritarismos e práticas violentas, diversas organizações de defesa dos direitos humanos e de vítimas das ditaduras militares no Cone Sul se apoiam nas reivindicações em torno do slogan "Nunca Mais". Desse modo, essa noção de que lembrar gera uma consciência, de que a repetição 
E dentro do gênero documental destacamos os "documentários de memória", que para Tomaim (2016), são aqueles que mergulham no passado por meio dos indícios trazidos por suas testemunhas, sendo um tipo de obra em que as representações memorialísticas contidas em vestígios, materiais ou das palavras das testemunhas são fulcrais. Essa variedade da produção documentária se caracteriza por um distanciamento temporal relativo aos acontecimentos tratados, pela referência aos acontecimentos mediada tanto por testemunhos quanto por material de arquivo e pela inclusão dos próprios realizadores nos seus filmes. Outra particularidade desse tipo documental é a explicitação da marca autoral. Os cineastas, além de exercerem funções habituais, a exemplo da direção e da escrita do roteiro, também adentram na narrativa, seja por voz em off ou aparecendo em cena. (APREA, Gustavo, 2015 apud ARRIBA, María Laura de, 2020)

Nichols (2016) enumera duas grandes tradições documentárias: uma ligada aos produtores norte-americanos e britânicos, na qual há uma tendência a uma linguagem de tons expositivos e descritivos, e outra, típica dos cineastas europeus continentais e latinoamericanos, que é bem mais propícia para narrativas abertamente intimistas. De forma semelhante, Valenzuela (2006) sinaliza que a memória, seja a individual ou a coletiva, é parte fundamental de boa parte dos documentários latino-americanos, nos quais a narração em primeira pessoa denota uma relação afetiva do/a realizador/a com os tema tratados, afastando uma lógica puramente informativa e privilegiando a utilização de diversos artifícios da linguagem cinematográfica e o entrelaçamento de memórias singulares com as coletivas.

Assim, de acordo com Valenzuela (2006), no Chile, o número de exemplares dessa forma contemporânea de se fazer cinema documental está aumentando significamente, bem como o interesse por filmes que, ao falar de vivências particulares dos/as seus/as autores/as, também referem-se à própria história do país. Se o cinema documentário das décadas de 1960 e 1970 possuía um viés engajado, panfletário em alguns casos e objetivava elaborar sínteses totalizantes dos fatos históricos, no produzido a partir dos anos 1980 e 1990, há muito mais destaque para o relato pessoal e uma leitura do passado que opera nas fronteiras das

de fatos traumáticos e a interdição do passado são inadmissíveis é muito cara às famílias dos desaparecidos e às organizações defensoras dos direitos humanos. 
experiências pessoais dos/as cineastas e dos/as seus/as personagens com a memória social. (BARRENHA, 2013)

Deste modo, filmes como Nostalgia de la Luz, estruturados a partir do testemunho, configuram uma narrativa que nos chama a atenção para um imperativo: a repetição dos traumas e a interdição do debate sobre os crimes do Estado são inadmissíveis. Sendo assim, as demandas em torno do passado autoritário, sintetizadas nas buscas por verdade, memória e justiça, mais que as busca por definições inequívocas, são os conceitos-chave na compreensão do testemunho.

En este punto podría decirse que se diluyen las diferencias: se trata de un género político por excelencia en el que la búsqueda de la verdad apunta a la esperanza de lograr el cumplimiento de justicia - al menos de un poco de justicia. Verdad, justicia, memoria son los términos que lo definen como un discurso ético-político; más allá de todo intento de clasificación, el eje que lo estructura es siempre una postura ética (SÁNCHEZ, 2020, p.36)

Ana María Amar Sanchéz (2020) nos diz que no gênero testemunhal os elos entre os sujeitos (narradores ou partícipes do relato) e a verdade são essenciais. A autora identifica essa verdade com a ética, mas não desenvolve esse tópico. Interpretamos, então, que essa verdade não é simplesmente da ordem do "factual", mas, sobretudo, de um compromisso moral das testemunhas que sobreviveram ao terror: a necessidade de se contar o que elas passaram.

Para quem testemunha em Nostalgia de la Luz, o relato adquire uma condição tão importante quanto as funções biológicas mais elementares. Os vitimados querem ser escutados e transmitir a desumanização sofrida. Os testemunhos de Patricio Guzmán, Violeta Berríos, Vicky Saavedra, Luis Henríquez e Miguel Lawner denotam que o desejo de narrar impulsiona a resistência e a luta pela preservação da memória, bem como a honra aos que partiram e a tentativa de se reconstruir vivências fragilizadas pela violência estatal.

Temos a hipótese de que filmes como Nostalgia de la Luz podem ser lidos enquanto testemunhos fílmicos, pois expressam uma vontade basilar de se registrar, no espaço público, de que maneiras os corpos, subjetividades e identidades foram afetadas pela máquina repressiva. Por conseguinte, a ética do testemunho, seja este literário ou cinematográfico, poderia relacionar-se, segundo a nossa inferência, com a possibilidade de se inscrever os 
traumas individuais na memória social e de se partilhar da noção de que a luta da memória é um componente básico dos valores democráticos.

Entendemos assim que Nostalgia de la Luz se opõe às operações da degenação, que provocam aquilo que Richard Vynes (2015) denonima de "privatização da memória": a clausura de determinadas recordações no âmbito privado, impedidas de chegar até o mundo público. Os sujeitos e grupos que sofrem com essa privatização, segundo o autor, dificilmente conseguem reconhecer-se dentro de uma história coletiva mais ampla e isso gera invisibilidades no dito espaço público.

\section{Considerações Finais}

É inegável que o Estado Chileno, nas últimas décadas, vem promovendo políticas em relação ao passado da recente ditadura e ações significativas no campo da justiça de transição. Nesse sentido, destacamos: as Comissões Rettig ${ }^{24}$ e $V^{2} \operatorname{lech}^{25}$, a construção de espaços museológicos, como o Museu da Memória e dos Direitos Humanos, em 2010, e a ressignificação de dois lugares que foram palcos de tortura, sequestro e assassinato, a Villa Grimaldi e a Casa Londres n³8, utilizada pela DINA. Em 1997 e 2008, esses locais foram rebatizados, respectivamente, como Parque por la Paz Villa Grimaldi e Espacio de Memoria Londres 38. Eles se converteram em lugares de memória que conservam testemunhos e documentos que

\footnotetext{
${ }^{24}$ A Comisión Nacional de Verdad y Reconciliación (também conhecida como Rettig, devido ao seu presidente, o advogado e político Raúl Rettig) foi estabelecida em abril de 1990 e teve o seu relatório entregue em fevereiro do ano seguinte. O propósito dessa Comissão era investigar os casos de violações de direitos humanos que resultaram em mortes e/ou desaparecimentos no período de 11 de setembro de 1973 a 11 de março de 1990. Foram recebidas em torno de 3.400 denúncias, das quais 2.279 foram classificadas como casos de óbito. Para dar sequência aos trabalhos da Comission Rettig, em fevereiro de 1992, é criada a Corporación Nacional de Reparación y Reconciliación, que, em 1996, divulga o seu informe, que acrescentou 899 pessoas à lista de vítimas, somando cerca de 1200 desaparecidos/as e 3.000 mortos/as.

${ }^{25}$ A Comisión Nacional sobre Prisión Política y Tortura, chamada como Valech por conta do seu presidente, Sergio Valech, foi instituída em 2003. Se a Comissíon Rettig tratou das vítimas ausentes (os executados e os desaparecidos), a Valech investigou as ocorrências dos sobreviventes, que passaram pelos lugares que serviram como centros de detenção e tortura. Em novembro de 2004, é divulgado o Informe Valech, que reconheceu 27.255 pessoas como vítimas e a existência de 1.132 lugares utilizados para se cometer os delitos abarcados no escopo do informe. Em fevereiro de 2010 foi criada a Comisión Asesora Presidencial para la Calificación de Detenidos Desaparecidos, Ejecutados Políticos y Víctimas de Prisión Política y Tortura, composta pelos mesmos integrantes da Comissão Valech. O Informe desta Comissão acrescentou mais 30 casos de presos desaparecidos e executados políticos e 9.795 de prisão política e tortura, aumentando para cerca de 40.000 o contingente de pessoas mortas, torturadas, desaparecidas e detidas na ditadura por razões políticas.
}

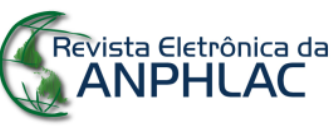

Revista Eletrônica da ANPHLAC, ISSN 1679-1061, № 29, p.127-156, Ago./Dez., 2020. http://revista.anphlac.org.br 
mostram a materialidade do Terrorismo de Estado e que promovem diferentes ações educativas de valorização e promoção dos direitos humanos.

Embora tais iniciativas que dizem respeito à justiça no seu âmbito simbólico sejam significativas, segundo os depoimentos dos personagens de Nostalgia de la Luz, a dimensão formal da justiça é a que talvez mais importe. É essa dimensão que pode gerar maiores mudanças e ser mais efetiva na desmontagem dos arranjos conservadores e das marcas do autoritarismo.

Essas políticas são muito importantes, já que conseguem dar visibilidade aos apelos contidos no "Nunca Mais" e à memória dos/as vitimados/as. Todavia, elas devem ser acompanhadas de outras iniciativas, especialmente das condenações efetivas aos agentes da repressão. Entende-se que a criação de comissões para investigar os crimes de lesa humanidade e de espaços museológicos são atitudes bastante significativas e que representam uma dimensão simbólica de reparação. Todavia, os/as atingidos/as pela ditadura muito provavelmente anseiam que haja também justiça no seu aspecto concreto, ou seja, que não haja mais impunidade aos envolvidos nas graves violações de direitos humanos e que eles sejam responsabilizados judicialmente.

E mesmo essas Comissões, que visam esclarecer as circunstâncias das violações de direitos humanos, de acordo com os testemunhos do filme, não conseguiram determinar parte significativa do paradeiro dos desaparecidos e nem conseguiram desfazer a desmemória. Violeta afirma que as alegações do Estado não convencem. Gaspar Galaz verbaliza que as mulheres de Calama deveriam ser muito mais respeitadas e valorizadas, e também diz que embora haja similaridades entre os trabalhos dos astrônomos e das mulheres, há uma diferença abismal: os astrônomos investigam um passado que não lhes causa desconforto, enquanto as mulheres não devem conseguir repousar. E Guzmán se pergunta por que há ossos identificados que estão expostos em museus e outros, como os dos desaparecidos do regime pinochetista, que não são tratados com o mesmo desvelo.

Interpretamos que Nostalgia de la Luz trabalha a memória, e tal atitude significa que os personagens do documentário não se lembram unicamente para denunciar os horrores da ditadura, mas também para subsidiar possíveis transformações no tempo corrente e elaborar 
projetos de futuro. Assim, a memória é uma força que impulsiona modificações no status quo. Segundo o nosso olhar, Nostalgia de la Luz é um documentário que suscita muitas perguntas apaixonantes. Trata-se de uma obra que seguramente convida os/as historiadores/as a pensarem, com zelo, sobre a dimensão ética e empática diante das inquietações em torno de "um passado que não passa", que se manifesta por meio das memórias de quem, mesmo tendo a vastidão de um deserto como obstáculo, busca reunir os rastros de experiências pessoais e coletivas fraturadas.

\section{Referências Bibliográficas}

AGUIAR, Carolina Amaral de. A História Objeto do Filme, o Filme Objeto da História. In: Paixão de Memória: Patricio Guzmán. São Paulo: Instituto Vladmir Herzog, 2017, p. 14-23.

AGUIAR, Carolina Amaral de. O Chile na Obra de Chris Marker: Um Olhar para a Unidade Popular desde a França. 2013. Tese (Doutorado em História Social) - Faculdade de Filosofia, Letras e Ciências Humanas, Universidade de São Paulo, São Paulo, 2013. Disponível em: https://teses.usp.br/teses/disponiveis/8/8138/tde-13082013-144044/pt-br.php. Acesso em: 12 ago. 2020.

BARRENHA, Natalia Christofoletti. Herdeiros do Exílio: Memória e Subjetividade em Três Documentários Chilenos Contemporâneos. In: Doc On-line, ${ }^{\circ}$ 15, dez. 2013, p.195-228. Disponível em. http://doc.ubi.pt/15/dossier_natalia_barrenha.pdf. Acesso em: 12 ago. 2020.

BASILE, Teresa; CHIANI, Miriam. Introduccíon. In: (orgs). Voces de La Violencia: Avatares del Testimonio en el Cono Sur. EDULP, La Plata, 2020, p. 8-31

BAUER, Caroline Silveira. Brasil e Argentina: Ditaduras, Desaparecimentos e Políticas de Memória. $2^{a}$ edição. Porto Alegre: Medianiz, 2014a, 330 p.

BAUER, Caroline Silveira. Como Será o Passado? História, Historiadores e a Comissão Nacional da Verdade. Jundiaí, SP, Paco, 2017, 240 p.

BISPO, Bruno Vilas Boas. Imagens de uma Utopia Latino-americana: A Batalha do Chile, Filme de Patricio Guzmán. Curitiba, Appris, 2019, 219 p.

CÓRTES, Carolina Pizarro. Formas Narrativas del Testimonio. In: CAPPELLINI, Serena; SCARABELLI, Laura (orgs). Donde No Habite El Olvido: Herencia Y Transmisión Del Testimonio En Chile. Di/Segni, Milão, 2017, p. 23-42. 
DÁVILA, Ignacio Del Valle. O Conceito De "Novidade" No Projeto Do Nuevo Cine Latinoamericano. In: Revista Estudos Históricos, Rio de Janeiro, v. 26, n. 51, p. 173-192, ago. 2013. Disponível em: http://bibliotecadigital.fgv.br/ojs/index.php/reh/article/view/7197. Acesso em: 12 ago. 2020.

DÁVILA, Ignacio Del Valle. Os Esquecidos Anos 1980: Patricio Guzmán e a Resistência Espiritual Latinoamericana. In: Paixão de Memória: Patricio Guzmán. São Paulo: Instituto Vladmir Herzog, 2017, p.24-35.

DIDI-HUBERMAN, Georges. Ante el Tiempo: Historia del Arte y Anacronismo de las Imágenes. $3^{\text {a }}$ edição. Adriana Hidalgo Editora: Buenos Aires, 2011.

DORFMAN, Ariel. O Longo Adeus A Pinochet. Trad. de Rosa Freire d'Aguiar. São Paulo: Companhia das Letras, 2003, 200 p.

FRANCO, Marina; LEVÍN, Florencia. El Pasado Cercano En Clave Historiográfica. In: (orgs). Historia Reciente: Perspectivas y Desafíos Para Un Campo En Construcción. Buenos Aires, Editorial Paidós, 2007, p. 31-65.

GAGNEBIN, Jeanne Marie. Lembrar, Escrever, Esquecer. São Paulo: Editora 34, 2006, 224 p.

GAGNEBIN, Jeanne Marie. O Preço de uma Reconciliação Extorquida. In: TELES, Edson; SAFATLE, Vladimir (orgs). O Que Resta da Ditadura: A Exceção Brasileira. São Paulo: Boitempo, 2010, p.177-186.

GINZBURG, Jaime. A Interpretação do Rastro em Walter Benjamin. In: Walter Benjamin, Rastro, Aura e História. UFMG, 2012, p. 107-132. ; SEDLMAYER, Sabrina (orgs). Belo Horizonte: Editora

GUZMÁN, Patricio. Filmar O Que Não Se Vê: Um Modo de Fazer Documentários. Trad. de José Feres Sabino. São Paulo: Edições Sesc, 2017, 288 p.

HUYSSEN, Andreas. Prólogo: Medios y Memoria. In: FELD, Claudia; MOR, Jessica Stites (orgs). El Pasado Que Miramos: Memoria E Imagen Ante La Historia Reciente. Buenos Aires, Paidós, 2009, p. 15-23.

JELIN, Elizabeth. Los Trabajos de La Memoria. Siglo XXI: Madrid, 2002, 147 p.

LIRA, Elizabeth. Reflexiones Sobre Memoria y Olvido Desde Una Perspectiva Psicohistórica. In: GARCÉS, Mario; MILOS, Pedro; OLGUÍN, Myriam; PINTO, Julio; ROJAS,María Teresa; URRUTIA, Miguel (orgs). Memoria Para Un Nuevo Siglo: Chile, Miradas a la Segunda Mitad del Siglo XX. Santiago: LOM Ediciones, 2000, p. 61-92. 
NICHOLS, Bill. Introdução Ao Documentário. Trad. de Mônica Sandy Martins. $6^{\mathrm{a}}$ ed. Campinas, SP: Papirus, 2016, 336 p.

PADRÓS, Enrique Serra. Memória e Esquecimento Das Ditaduras De Segurança Nacional: Os Desaparecidos Políticos. In: História Em Revista, Pelotas, nº 10, dez. 2004, p.1-16. Disponível em:

https://periodicos.ufpel.edu.br/ojs2/index.php/HistRev/article/view/11658/7488. Acesso em: 12 ago. 2020.

RICHARD, Nelly. Crítica de La Memoria. Santiago: Ediciones Universidad Diego Portales, 2010, 270 p.

SÁNCHEZ, Ana María Amar. El Narrador, El Testigo, La Víctima: Los Sujetos Del Testimonio. In: BASILE, Teresa; CHIANI, Miriam (orgs). oces de La Violencia: Avatares del Testimonio en el Cono Sur. EDULP, La Plata, p. 33-52.

SARLO, Beatriz. Tempo Passado: Cultura da Memória e Guinada Subjetiva. Trad. de Rosa Freire D’aguiar. São Paulo: Companhia das Letras; Belo Horizonte: Editora UFMG, 2007, 136 p.

SELIGMANN-SILVA, Márcio. Ficção E Imagem, Verdade E História: Sobre A Poética Dos Rastros. In: Dimensões, Vitória, vol. 30, 2013, p. 17-51. Disponível em: https://periodicos.ufes.br/dimensoes/article/view/6144. Acesso em 12 ago. 2020.

SELIGMANN-SILVA, Márcio. Narrar o Trauma: a Questão dos Testemunhos de Catástrofes Históricas. In: Psicologia Clínica, Rio de Janeiro, 2008, vol.20, n.1, p..65-82. Disponível em:https://www.scielo.br/pdf/pc/v20n1/05. Acesso em: 12 ago. 2020.

SELIGMANN-SILVA, Márcio. Testemunho E A Política Da Memória: O Tempo Depois Das Catástrofes. In: Projeto História, São Paulo, v. 30, dez. 2005, p.71-98. Disponível em: https://revistas.pucsp.br/revph/article/view/2255/1348. Acesso em: 12 ago. 2020.

SHAFIR, Isabel Piper. Memorias de La Violencia Política En Chile: 1970-2014. In: Anos 90, Porto Alegre, v.22, $\mathrm{n}^{\mathrm{o}}$ 42, dez. 2015, p.179-191. Disponível em: https://seer.ufrgs.br/anos90/article/view/52958/36146. Acesso em: 12 ago. 2020.

TODOROV, Tzvetan. Los Abusos de la Memoria. Barcelona: Ediciones Paidós Ibérica, 2000, $109 \mathrm{p}$.

TOMAIM, Cássio dos Santos. O Documentário Como Mídia De Memória: Afeto, Símbolo E Trauma Como Estabilizadores Da Recordação. In: Significação: Revista de Cultura 
Audiovisual, São Paulo, v. 43, n. 45, p. 96-114, ago. 2016. Disponível em: http://www.revistas.usp.br/significacao/article/view/111443. Acesso em 12 ago. 2020.

VALENZUELA, Valeria. Yo Te Digo que El Mundo Es Así: Giro Performativo en el Documental Chileno Contemporáneo. In: Doc On-Line, Covilhã, nº 01, dez/ 2006, p.6-22. Disponível em: http://doc.ubi.pt/01/artigo_valeria_valenzuela.pdf. Acesso em: 12 ago. 2020.

VINYES, Richard. Sobre Vítimas e Vazios, Ideologias e Reconciliações, Privatizações e Impunidades. In: QUADRAT, Samantha Viz; ROLLEMBERG, Denise (orgs). História e Memória das Ditaduras do Século XX. Volume 2. Rio de Janeiro: Editora FGV, 2015, p. 224244. 